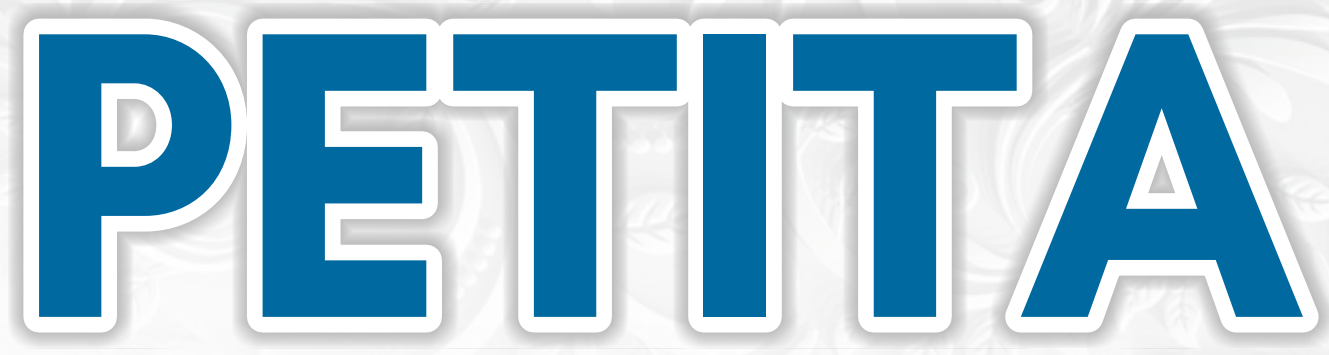

Jurnal Kajian Ilmu Hukum dan Syariah

Published By:

Lembaga Kajian Konstitusi Indonesia (LKKI)

Fakultas Syariah dan Hukum Universitas Islam Negeri (UIN) Ar-Raniry Banda Aceh Jl. Syeikh Abdul Rauf, Kopelma Darussalam Banda Aceh, Telp: 0651-7557442 Website: http://petita.ar-raniry.ac.id 


\section{Contents}

TES DNA SEBAGAI ALAT BUKTI PENGGANTI EMPAT ORANG SAKSI (ANALISIS QANUN ACEH NOMOR 6 TAHUN 2014 TENTANG HUKUM JINAYAH)

(Era Fadli, Mursyid Djawas \& Syarifah Rahmatillah / 1-9)

SISTEM JAMINAN KESELAMATAN KERJA KARYAWAN BENGKEL LAS MENURUT PERSPEKTIF HUKUM ISLAM DAN UNDANG-UNDANG NO.13 TAHUN 2003 TENTANG KETENAGAKERJAAN (Studi Kasus Kecamatan Tanah Jambo Aye)

(Lilis Diatana, Edi Darmawijaya \& Faisal Fauzan / 10-23)

PERTANGGUNGAN RISIKO TERHADAP SEJUMLAH MINYAK YANG SUSUT DALAM MASA PENGANGKUTAN (Studi Kasus pada PT.Citra Bintang Familindo)

(Mayliza / 24-35)

KEDUDUKAN MEMORANDUMOF UNDERSTANDING (MOU) HELSINKI DALAM PEMBENTUKAN UNDANG- UNDANG NOMOR 11 TAHUN 2006 TENTANG PEMERINTAHAN ACEH

(Qonita Royani Salpina, Rusjdi Ali Muhammad \& Yenny Sriwahyuni / 36-46)

PELELANGAN OBJEK JAMINAN MURABAHAH PADA BANK SYARIAH MANDIRI CABANG BANDA ACEH MELALUI KANTOR PELELANGAN KEKAYAAN NEGARA DAN LELANG DALAM PERSPEKTIF BAI' AL-MUZAYYADAH

(Reza Fahmi / 47-63)

PENERAPAN SANKSI TINDAK PIDANA ILLEGAL LOGGING DI KAWASAN HUTAN LINDUNG DITINJAU DARI DARI UU NO. 18 TAHUN 2013 TENTANG PENCEGAHAN DAN PEMBERANTASAN PERUSAKAN HUTAN (Studi Kasus Kecamatan Bener Kelipah Kabupaten Bener Meriah)

(Ali Abu Bakar, Mizaj Iskandar \& Reza Maulana / 64-74)

EFEKTIVITAS PELAKSANAAN SANKSI TALAK DI LUAR MAHKAMAH RENDAH SYARIAH (STUDI KASUS DI MAHKAMAH RENDAH SYARIAH SELANGOR, MALAYSIA)

(Rukiah M. Ali \& Siti Maimunah Binti Mohd Rijal / 75-95)

SISTEM PERLINDUNGAN PEMKAB ACEH BESAR TERHADAP PERTAMBANGAN BATUAN DALAM PERSPEKTIF MILK AL-DAULAH (PENELITIAN PADA TAMBANG BATUAN DI KECAMATAN INDRAPURI)

(Siti Rohaya / 96-103) 
PETITA: Jurnal Kajian Ilmu Hukum dan Syariah

Volume 3, Number 1, 2018

P-ISSN: 2502-8006 E-ISSN: 2549-8274

DOI: https://doi.org/10.22373/petita.v3i1.29

\title{
SISTEM JAMINAN KESELAMATAN KERJA KARYAWAN BENGKEL LAS MENURUT PERSPEKTIF HUKUM ISLAM DAN UNDANG-UNDANG NO.13 TAHUN 2003 TENTANG KETENAGAKERJAAN (Studi Kasus Kecamatan Tanah Jambo Aye)
}

\author{
Lilis Diatana, Edi Darmawijaya \& Faisal Fauzan \\ Hukum Ekonomi Syari'ah, Fakultas Syari'ah dan Hukum, UIN Arraniry \\ Email: lilisdiatana@ar-raniry.ac.id
}

\begin{abstract}
Abstrak: The employee safety is the responsibility of a company often ignored. The company is not optimal in doing safety effort for employees become one of its trigger. Welding garages in the sub-district of Tanah Jambo Aye is the company engaged in welding which has high level of potential hazard. In addition, the workers have to obtain the word safety that was listed in the law No. 13 year 2003 about employment. The problems will be discussed in this thesis are: (1) How is the employee safety guarantees system of welding garage in Tanah Jambo Aye sub-district? (2) How is the Islamic law perspective and the law No.13 year 2003 on the employee safety guarantees system of welding garage in Tanah Jambo Aye sub-district?. The first purpose of this research to know how is the employee safety guarantees system of welding garage in Tanah Jambo Aye. The last is to know how is the Islamic law perspective and the law No.13 year 2003 on the employee guarantees system of welding garage in Tanah Jambo Aye sub-district. The research methodology that is used in this research is descriptive analysis of Qualitative method. The result show the welding garage in Tanah Jambo Aye sub-district is less effective and not go well yet, because the welding garage company in that district do not provide perfect tool for personal protection in safety working, such as: hand protectors, masker, shoes, hat protections, and face protections. The risk happened in working or work accident can cause the employees disabled or injury, the all cases is not in full responsibility by the welding garage in Tanah Jambo Aye sub-district. This case less corresponding with Islamic concept, as intended in Maqashid Syari'ah by maintaining Al-umur al-dharuruyah that are maintaining the soul, religion, mind, descent, and treasure. Therefore, it can safety guarantee of the world and hereafter.
\end{abstract}

\section{Keywords: Welding Garage, Employee Safety, Islamic law, Employment Law}

Abstrak: Keselamatan pekerja Merupakan Tanggung jawab perusahaan yang sering diabaikan oleh perusahaan, salah satu penyebabnya adalah kurang optimalnya perusahaan dalam menyelenggarakan upaya keselamatan bagi karyawannya. Bengkel Las Kecamatan Tanah Jambo Aye merupakan perusahaan yang bergerak dIbidang pengelasan yang memiliki tingkat potensi bahaya tinggi. Selain itu Keselamatan Kerja juga merupakan hak yang harus diperoleh pekerja yang sudah tercantum dalam Undang-undang No. 13 Tahun 2003 Tentang Ketenagakerjaan. Adapun Permasalahan yang di bahas dalam skripsi ini adalah: (1) Bagaimana Sistem Jaminan Keselamatan kerja Karyawan Bengkel Las Kecamatan Tanah Jambo Aye? (2) Bagaimana tinjauan Hukum Islam dan Undang-undang No.13 Tahun 2003 terhadap Sistem Jaminan Keselamatan kerja Karyawan Bengkel Las Kecamatan Tanah Aye? Tujuan Penelitian ini adalah Untuk mengetahui Bagaimana Sistem Jaminan keselamatan kerja Karyawan Bengkel Las Kecamatan Tanah Jambo Aye. Dan untuk mengetahui bagaimana tinjauan Hukum Islam dan Undang-undang No.13 Tahun 2003 
terhadap Sistem Jaminan keselamatan Karyawan Bengkel Las Kecamatan Tanah Aye?. Metode yang digunakan dalam penelitian ini adalah metode Kualitatif yang berbentuk deskriptif analisis. Hasil Penelitian Menunjukkan bahwa Bengkel Las Kecamatan Tanah Jambo Aye dalam Melaksanakan Jaminan Keselamatan Kerja kurang Maksimal dan belum berjalan dengan baik karena Bengkel Las Kecamatan Tanah Jambo Aye belum sempurna dalam menyediakan alat-alat pelindung diri untuk keselamatan kerja Seperti: alat pelindung tangan, masker, sepatu, topi pelindung, alat pelindung wajah. Dan Bentuk Risiko yang terjadi dalam melakukan pekerjaan atau kecelakaan kerja yang dapat mengakibatkan para pekerja cacat ataau luka-luka, semua itu tidak di tanggung penuh oleh Bengkel Las Kecamatan Tanah Jambo Aye. Hal ini kurang sesuai dengan konsep Islam, sebagaimana yang dimaksud dalam Maqashid Syari'ah dengan memelihara Al-umur al-dharuriyah yaitu memelihara jiwa, agama, akal, keturunan dan harta sehingga dapat terjamin keselamatan dunia dan akhirat.

Kata Kunci: Bengkel Las, Keselamatan Kerja, Hukum Islam, Hukum Ketenagakerjaan.

\section{PENDAHULUAN}

Setiap manusia yang hidup didunia memiliki kebutuhan yang beragam. Oleh karena itu untuk memenuhi kebutuhan tersebut manusia dituntut harus bekerja. Baik pekerjaan yang diusahakan sendiri, ataupun bekerja pada orang lain sebagai karyawan. ${ }^{1}$ Pekerja merupakan bagian terpenting pada suatu perusahaan, karena Tanpa ada pekerja kemungkinan suatu perusahaan tidak bisa bertahan dan berpartisipasi dalam pembangunan nasional. Kesejahteraan pekerja haruslah menjadi tanggungan perusahaan guna menjamin keselamatan para pekerja atau karyawan.

Jaminan terhadap karyawan adalah salah satu tujuan yang harus dicapai dalam dunia usaha baik itu pengusaha, maupun pekerja itu sendiri. Dan ini sesuai dengan pemikiranpemikiran dunia yang menuntut perlunya kenyamanan dan keamanan manusia dalam bekerja. $^{2}$ Suatu perusahaan mempunyai kewajiban untuk mensejahterakan para pekerjanya, yaitu dengan memberikan lingkungan kerja yang aman dan sehat serta memenuhi semua kebutuhan yang bersifat jasmaniah dan rohaniah, baik didalam maupun di luar hubungan kerja. ${ }^{3}$

Sebuah perusahaan harus menyediakan Alat Pelindung Diri (APD) guna untuk mencegah risiko kecelakaan yang diakibatkan oleh Bengkel Las. Jika sebuah perusahaan melaksanakan tindakan-tindakan keselamatan yang efektif, maka lebih sedikit pekerja yang menderita cedera sebagai akibat dari pekerjaan mereka pada perusahaan tersebut. ${ }^{4}$ Dalam kehidupan ini kita sebagai manusia selalu dihadapkan dengan berbagai macam risiko, pertama risiko yang bersifat merugikan, seperti risiko bisnis, risiko kecelakaan, dan risiko sakit. Risiko adalah ketidak pastian yang mendatangkan kerugian. ${ }^{5}$ Risiko dalam hubungan kerja, seperti kematian atau cacat baik fisik maupun mental yang dialami oleh pekerja karena kecelakaan kerja.

Manusia harus mencegah musibah dan kemalangan, serta mengupayakan berbagai cara dalam mencegah risiko yang terjadi, diantaranya adalah mengupayakan cara untuk sama-sama saling membantu, saling menanggung dan saling melindungi. ${ }^{6}$ Memberika

$1 \quad$ Zainal Asikin, Dasar-Dasar Hukum Perburuhan (PT Raja Grafindo Persada 2006), hlm. 1.

2 Basir Barthos, Manajemen Sumber Daya Manusia, Suatu Pendekatan Makro (Bumi Aksara 2001), hlm. 136.

3 Oktav P. Zamani, Pedoman Hubungan Industrial (PPM 2011), hlm. 67.

$4 \quad$ Abdul Rosyid, Manajemen Sumber Daya Alam Manusia (Erlangga 1999), hlm. 222.

$5 \quad$ Khoiril Anwar, Asuransi Syariah, Halal Dan Maslahah (Tiga Serangkai), hlm. 6.

6 Muhammad Syakir Sula, Asuransi Syariah (Life and General): Konsep Dan Sistem Operasional (Gema Insani Press 2004), hlm. xviii. 
perlindungan hukum atau jaminan kepada pekerja yaitu amanah dan tujuan dari hukum ketenagakerjaan. Perlindungan hukum atau jaminan kepada pekerja dilakukan agar hak-hak pekerja tidak dilanggar oleh pengusaha. kewaspadaan terhadap pekerja itu juga sangat penting karena bahaya yang diakibatkan oleh pemakaian alat-alat teknologi yang canggih serta diperlukan untuk meningkatkan pengetahuan, keterampilan, ketangkasan didalam penggunaan alat-alat yang modern, dengan demikian kerugian atau risiko yang timbul dapat dicegah dan dekendali.

Menurut Undang-Undang No. 13 Tahun 2003 Tentang Ketenagakerjaan, tenaga kerja adalah setiap orang yang mampu melakukan pekerjaan guna menghasilkan barang atau jasa baik untuk memenuhi kebutuhan sendiri maupun untuk masyarakat. ${ }^{7}$ Sedangkan bagi pengusaha yang memperkerjakan tenaga kerja harus memperhatikan keamanan bagi karyawan ditandai dengan adanya kesempurnaan didalam lingkungan kerja, alat kerja, bahan kerja yang dikendalikan oleh sebuah sistem manajemen yang baik.

Beberapa pengamatan menunjukkan bahwa rasa aman dalam menjalankan tugas masih menjadi dambaan bagi pekerja. Yaitu: curahan bahan yang dapat menyebarkan partikelpartikel dari bahan industri yang menyebabkan sakit, pencemaran lingkungan oleh limbah industri pengolahan yang dapat mengganggu keamanan dan kenyamanan pekerja. ${ }^{8}$

Dalam Undang-Undang No. 13 Tahun 2003 Tentang Ketenagakerjakaan Keselamatan dan kesehatan tenaga kerja diselenggarakan untuk melindungi keselamatan pekerja guna untuk mewujudkan produktivitas kerja yang optimal. Upaya keselamatan dan kesehatan kerja dimaksudkan untuk memberikan jaminan keselamatan dan meningkatkan derajat kesehatan para pekerja dengan cara pencegahan kecelakaan dan penyakit akibat kerja, pengendalian bahaya ditempat kerja, promosi kesehatan, pengobatan dan rehabilitasi.

Hukum Islam juga telah mengatur bahwa setiap individu mempunyai hak dalam kehidupan yang layak, serta perusahaan mempunyai kewajiban untuk menyiapkan sarana-sarana pengaman atau Alat Pelindung Diri (APD) ditempat kerja guna melindungi karyawan dari bahaya dan penyakit-penyakit yang disebabkan dengan risiko pekerjaannya. Itu bisa dihindari jika diperoleh kepastian tentang keselamatan atau kelayakan alat dan perkakas yang ditempatkan di bawah pengaturan perusahaan. ${ }^{9}$

Dalam Islam juga telah dijelaskan masalah maqasid syari'ah yang terdiri dari dua kata, maqasid yang artinya tujuan dan syari'ah artinya hukum-hukum Allah yag ditetapkan untuk manusia agar dipedomani untuk mencapai kebahagian hidup didunia maupun diakhirat. Menurut Imam As-Syathibi, Allah menurunkan syariat (aturan hukum) yaitu untuk kemaslahatan dan menghindari kemudharatan, dan aturan-aturan hukum yang Allah tentukan hanyalah untuk kemaslahatan manusia itu sendiri. Maqasid syari'ah ada lima yaitu: Melindungi agama (al-din), melindungi akal (al-aql), melindungi keluarga (al-ird), melindungi harta (al-mal), dan melindungi nyawa (al-nafs) yaitu menjaga jiwa atau nyawa seseorang. Dalam agama Islam nyawa manusia adalah sesuatu yang sangat berharga dan harus dijaga serta dilindungi. Seorang muslim dilarang membunuh orang lain atau dirinya. ${ }^{10}$

Maka dari itu Islam sangat menganjurkan dalam melakukan setiap pekerjaan harus selalu mengutamakan keselamatan dirinya maupun orang lain agar terhindar dari hal-hal yang tidak diinginkan. Jaminan keselamatan kerja bertujuan untuk menjamin berlangsungnya

$7 \quad$ Agusmidah, Hukum Ketenagakerjaan Indonesia (Ghalia Indonesia 2010), hlm 6.

8 Basir Barthos, Manajemen Sumber Daya Manusia Suatu Pendekatan Makro (Bumi Aksara 2012), hlm. 154.

9 Baqier Sharief Qorashi, Keringat Buruh, Hak Dan Peran Pekerja Dalam Islam (Al-huda 2007), hlm. 251.

Ahmad Munif Suratmaputra, Filsafat Hukum Islam Al-Ghazali (Pustaka Firdaus 2002), hlm. 70. 
sistem hubungan kerja secara harmonis tanpa disertai adanya tekanan dari pihak yang kuat kepada pihak yang lemah. Maka dari itu pengusaha wajib melaksanakan ketentuan jaminan keselamatan tersebut sesuai dengan peraturan perundang-undangan.

Dalam penelitian ini penulis mengambil data dari 4 Bengkel Las yang ada di Kecamatan Tanah Jambo Aye ke empat bengkel tersebut yaitu: Bengkel Global, Bengkel Rizki Stell, Bengkel Palapa, dan Bengkel Briesend. Bengkel Global memperkerjakan 12 0rang karyawan yang rata-rata berusia 30 tahun dengan gaji perbulan 1.500 .000 .00 , Bengkel Rizki Stell memperkerjakan 13 karyawan yang rata-rata berusia 25 tahun dengan gaji perbulan 2.000.000, kemudian Bengkel Palapa memperkerjakan 15 karyawan yang ratarata berusia 20 sampai 35 tahun dengan gaji perbulan 3.000.000, selanjutnya Bengkel Briesend memperkerjakan 10 karyawan yang rata-rata berusia 22 tahun dengan gaji perbulan 2.500.000.11

Dalam ketentuan jaminan keselamatan kerja, seharusnya Keempat Bengkel Las tersebut harus memberikan jaminan keselamatan kerja kepada karyawannya. Akan tetapi pada kenyataannya jika ada kecelakaan yang diakibatkan oleh Bengkel Las maka para karyawan harus membayar sendiri biaya kecelakaan yang terjadi tersebut. Dalam proses kegiatan bekerja sehari-hari para pekerja tidak memakai Alat Pelindung Diri (APD), hal ini dikarenakan pihak Bengkel Las tidak menyediakan dengan sempurna atau lengkap, seperti: sarung tangan ,topi pelindung, alat pelindung mata, alat pelindung wajah, alat pelindung tangan, alat pelindung pernafasan, dan alat pelindung kaki.

Alat Pelindung Diri (APD) tersebut sangat dibutuhkan oleh para pekerja untuk menjada dirinya agar terhindar dari kecelakaan. Kecelakaan kerja terhadap karyawan merupakan satu hal yang tidak dapat dihindari. Maka dari itu, setiap pengusaha harus memberikan jaminan keselamatan kerja terhadap karyawan dan menyediakan Alat Pelindung Diri (APD) yang lengkap supaya terhindar dari kecelakaan bagi karyawan .

Bentuk risiko yang sering terjadi pada karyawan Bengkel Las yaitu adanya kesalahan teknis yang berakibat fatal seperti rusak mata karena pekerja pada saat mengelas tidak memakai kaca mata, luka bakar ditelapak tangan karena pekerja tidak memakai sarung tangan, gangguan pernafasan yang berasal dari faktor zat kimia yang terdiri dari elektroda, asap, debu dan gas karena mereka tidak menggunakan masker penutup mulut, terbelah tangan terkena gerenda, dan terjepit kaki dengan besi. ${ }^{12}$

Mengingat kemungkinan risiko yang sangat tinggi terhadap para karyawan Bengkel Las. Maka penulis tertarik ingin meneliti "Sistem Jaminan Keselamatan kerja Karyawan Bengkel Las Menurut Perspektif Hukum Islam dan Undang-Undang No. 13 Tahun 2003 Tentang Ketenagakerjaan ( Studi Kasus Kecamatan Tanah Jambo Aye)".

Tujuan yang ingin dicapai oleh peneliti dalam penulisan karya ilmiah ini adalah:

1. Untuk mengetahui Bagaimana Sistem Jaminan keselamatan kerja Karyawan Bengkel Las di Kecamatan Tanah Jambo Aye.

2. Untuk mengetahui bagaimana tinjauan Hukum Islam dan Undang-undang No.13 Tahun 2003 terhadap Sistem Jaminan keselamatan Karyawan Bengkel Las di Kecamatan Tanah Jambo Aye? ]

\section{METODOLOGI PENELITIAN}

Penelitian ini menggunakan metode penelitian deskriptif analisis adalah metode yang

11 'Wawancara Dengan Razali, Pengusaha Bengkel Las Kecamatan Tanah Jambo Aye, Tanggal 2 September 2017.'

12 'Wawancara Dengan Muliadi, Karyawan Bengkel Las Kecamatan Tanah Jambo Aye, Tanggal 23 September 2017'. 
meneliti suatu kondisi, suatu peristiwa pada masa sekarang ini, yang tujuannya untuk membuat deskriptif, gambaran secara sistematika, faktual dan akurat mengenai faktafakta, dan hubungan antara fenomena yang diselidiki. ${ }^{13}$ Jenis penelitian yang digunakan dalam karya ilmiah ini adalah penelian studi lapangan yaitu penelitian yang dilakukan untuk mendapatkan data dengan cara meneliti dan mengobservasi lapangan terhadap sistem jaminan keselamatan kerja karyawan Bengkel las di kecamatan Tanah Jambo Aye. Penulis juga menghimpun data dengan wawancara dengan pemilik bengkel dan karyawan.

\section{LANDASAN TEORI}

\section{Jaminan}

Dalam Kamus Besar Bahasa Indonesia disebutkan bahwa jaminan adalah hal (perbuatan) menjamin. ${ }^{14}$ Jaminan hukum untuk memberikan perlindungan atau memberi jaminan hak seseorang untuk keselamatan dan terhindar dari mara bahaya. Jadi jaminan dalam pembahasan skripsi ini adalah sesuatu yang dapat melindungi seseorang (karyawan atau pekerja) dari risiko kerja berdasarkan kaidah dan norma serta segala aturan-aturan hukum yang berlaku terhadap pekerjaan yang menderita akibat suatu kejadian atau insiden yang merugikannya.

\section{Bengkel Las}

Bengkel Las merupakan sebuah nama yang selalu digunakan oleh perusahaan perorangan yang melayani pembuatan konstruksi besi dan sejenisnya, terutama kebutuhan berbahan dasar besi yang memerlukan pengelasan. Bengkel Las mempunyai pekerjaan yang unik yaitu bekerja berdasarkan pesanan yang mengerjakan sesuai keinginan pemesan. Bisa berupa perbaikan ataupun pembuatan seperti: besi, pagar/pintu minimalis, teralis pengaman, jendela, canopy. ${ }^{15}$

\section{Keselamatan Kerja.}

Keselamatan kerja merujuk kepada kondisi-kondisi fisiologis-fisikal pekerja yang diakibatkan oleh lingkungan kerja yang disediakan oleh perusahaan. ${ }^{16}$

\section{Hukum Islam}

Dalam Kamus Besar Bahasa Indonesia, hukum merupakan peraturan atau adat yang secara resmi dianggap mengikat, yang dikukuhkan oleh penguasa atau pemerintah untuk mengatur pergaulan hidup masyarakat. Islam adalah agama yang diajarkan oleh Nabi Muhammad saw. Berpedoman pada kita suci Al-Quran yang diturunkan ke dunia melalui wahyu Allah Swt. ${ }^{17}$ Hukum Islam merupakan peraturan dan ketentuan yang berkenaan dengan kehidupan berdasarkan Al-Quran dan hadist. Hukum Islam adalah seperangkat aturan yang berkaitan dengan segala aspek kehidupan manusia, baik dalam berhubungan dengan khaliq, dengan sesama dan hubungan dengan alam semesta.

\section{UU No.13 Tahun 2003 Tentang Ketenagakerjaan.}

Undang-Undang adalah hukum yang telah disahkan oleh badan legislatif atau unsur ketahanan yang lainnya. UU No.13 Tahun 2003 Tentang Ketenagakerjaan, yang di maksud dengan pada waktu sebelum, selama, dan sesudah masa kerja.

\section{HASIL PENELITIAN}

Kecamatan tanah jambo aye Merupakan salah satu dari 27 kecamatan di kabupaten

13 M.Nazir, Metode Penelitian (Ghalia Indonesia 1998), hlm. 63.

14 Departemen Pendidikan Nasional, Kamus Besar Bahasa Indonesia Pusat Bahasa (Gramedia 2008), hlm. 830.

15 Kasmir, Kewirausahaan (PT Raja Grafindo Persada 2006), hlm 24.

16 Veithzal Rivai, Manajemen Sumber Daya Manusia Untuk Perusahaan, Dari Teori Ke Praktik (PT Raja Grafindo Persada 2009), hlm 792. 
Aceh Utara, Provinsi Nanggro Aceh Darussalam (NAD). Luas kecamatan Tanah Jambo Aye 162,98 km²/ 16298 Ha. Kecamatan Tanah Jambo Aye meliputi 47 desa, dengan peringkat jumlah penduduk paling banyak berturut-turut Rawang Itik, Menasah Panton Labu, Kota panton Labu, Samakurok dan Teupin Gajah.

Batas Wilayah Kecamatan Tanah Jambo Aye meliputi sebelah utara dengan kecamatan seunuddon, sebelah barat dengan kecamatan seunuddon dan baktiya, sebelah selatan dengan kecamatan Baktiya dan Langkahan, serta sebelah timur dengan Kecamatan Langkahan dan Kabupaten Aceh Timur.

Wilayah Kecamatan Tanah Jambo Aye pada saat ini terdiri dari 4 kemukiman Yaitu:

1. Jambo Aye Tengoh

2. Jambo Aye Barat

3. Kota

4. Jambo aye Utara. ${ }^{18}$

Penduduk Merupakan unsur yang paling penting dalam membangun ekonomi,baik sebagai objek maupun subjek perekonomian itu sendiri. Dengan demikian, berarti bahwa aspek penduduk merupakan modal dasar dalam pelaksanaan perekonomian, aspek penduduk akan memberikan harapan sebagai salah satu sumber potensial yang menggerakkan dan digerakkan dalam proses perekonomian.

Berdasarkan pendataan, jumlah penduduk Kecamatan Tanah Jambo Aye pada akhir tahun 2015 berjumlah 47,432 jiwa, yang terdiri dari 23,903 penduduk laki-laki dan 23,592 penduduk Perempuan. Dengan perincian sebagai berikut: ${ }^{19}$

Usaha Bengkel Las merupakan usaha yang bergerak di bidang pengelasan yang menyediakan berbagai macam produk yang dapat dipesan dalam memenuhi kebutuhan masyarakat seperti pembuatan pagar, teralis, canopi, roling, balckon, tiang air, tower dan lain-lain.

Pada awalnya usaha bengkel las Di kecamatan Tanah Jambo Aye tidak begitu maju seperti saat sekarang ini. Dan masyarakat khususnya di kecamatan Tanah Jambo Aye juga belum banyak membuka usaha dalam bidang pengelasan. Namun melihat semakin banyaknya kebutuhan masyarakat akan rumah, maka salah satu usaha yang dapat di kembangkan di Kecamatan Tanah Jambo Aye adalah usaha bengkel las. Pada tahun 1998 salah seorang pengusaha bengkel las Bapak Razali kegiatan dalam memproduksi barang dan merangkai besi masih menggunakan gas sebagai bahan bakar. Atau istilah yang lebih dikenal adalah las MQD, dan ada juga yang menyebut las karbit. Jenis Las ini menggunakan campuran 2 jenis gas sebagai pembentukan nyala api dan sebagai sumber panas yang sering digunakan sebagai bahan bakar dibengkel adalah gas Asetelin.

Seiring Berkembangnya ilmu Pengetahuan dan teknologi, maka kegiatan didalam memproduksi barang juga semakin canggih. Pengusaha Bengkel las di Kecamatan Tanah Jambo Aye tidak lagi mggunakan MDQ dalam memproduksi barang. Namun mereka memproduksi melakukan pengelasan dengan listrik. Karna apabila menggunakan las jenis listrik maka akan dapat merangkai besi lebih kuat dan terjamin. ${ }^{20}$

Di kecamatan Tanah Jambo Aye jumlah Bengkel Las Terdapat 20 Bengkel Las yang mempunyai dua tipe Bengkel Las, yang pertama Bengkel Las yang sudah mempunyai

18 'Wawancara Dengan Nasruddin, Camat Kecamatan Tanah Jambo Aye, Pada Hari Senin, 25 Juni 2018, Di Aceh Utara.'

19 Ibid.

20 'Wawancara Dengan Razali, Pemilik Bengkel Kecamatan Tanah Jambo Aye, Pada Hari Rabu, 20 Juni 2018, Di Aceh Utara.' 
kapasitas yang besar yaitu sudah memiliki surat izin untuk mendirikan Bengkel Las tersebut, sedangkan Bengkel Las yang Kedua yang belum mempunyai kapasitas yang tinggi yang mana belum mempunyai surat izin untuk mendirikan Bengkel. Untuk masalah izin usaha, tidak semuanya Bengkel Las kecamatan tanah jambo Aye memiliki surat izin usaha. Hal ini disebabkan oleh kurangnya kesadaran dari pelaku usaha tentang pentingnya memiliki izin usaha, selain itu biaya yang sangat mahal juga menjadi kendala yang dialami oleh pengusaha Bengkel Las untuk mengurus izin usaha. ${ }^{21}$

Dalam Penelitian ini penulis mengambil data dari 4 Bengkel yang ada di Kecamatan Tanah Jambo Aye dan ke 4 Bengkel Las tersebut sudah mempunyai kapasitas yang besar yang s udah memiliki surat izin untuk mendirikan Bengkel Las. Ke 4 Bengkel Las tersebut yaitu Bengkel Global yang sudah berdiri selama 21 tahun dengan luas bengkel 15M. Bengkel Global memiliki pekerja sebanyak 12 orang, gaji karyawannya dihitung perbulan 1.500.000.0, jika sewaktu-waktu jumlah pekerjaannya banyak maka gaji karyawan bisa lebih tinggi, jam kerjanya bagi para pekerja di mulai dari jam 08.00: 06.00. Kemudian Bengkel Rizki Steel berdiri selama 12 tahun dengan luas bengkel 14M dengan jumlah pekerja sebanyak 13 orang dan sistem gajinya 2000.000 perbulan. jam kerja di mulai dari jam 08.00:06.00. Bengkel Palapa berdiri selama 18 tahun dengan luas 15M, memiliki jumlah pekerja sebanyak 15 orang. Gaji karyawannya 3000.000 perbulan, dan jadwal kerja di Bengkel Palapa di mulai dari jam 08.00: 06.00. Selanjutnya Bengkel Briesend berdiri selama 10 tahun dengan luas $10 \mathrm{M}$, jumlah karyawannya sebanyak 10 orang dengan gaji 2.500.000 perbulan. Jam kerjanya di mulai jam 08.00: 06.00 sore

Berdasarkan Keputusan Bengkel Las Kecamatan Tanah Jambo Aye menyatakan bahwa segala risiko yang terjadi dalam proses kinerja tidak penuh ditanggung oleh Bengkel Las tersebut, pihak Bengkel Las hanya menaggung sebagian saja. Meliputi bentuk-bentuk risiko yang tidak menjadi tanggungan Bengkel Las ialah sebagai berikut:

- Risiko Kecelakaan Kerja;

- Risiko Pemeliharaan Kesehatan;

\section{Risiko Kecelakaan Kerja}

Kecelakaan kerja adalah suatu kejadian yang tidak dapat diduga, tidak dikehendaki dan dapat menyebabkan kerugian baik jiwa maupun harta benda. Kecelakaan Kerja Meliputi luka/sakit,cacat, yaitu cacat tetap sebagian dan cacat tetap total.

Kecelakaan Kerja terjadi saat melaksanakan pekerjaan sesuai kewajiban dan tugas seharihari di tempat kerja. Di Bengkel Las Kecamatan Tanah Jambo Aye jika terjadi kecelakaan kerja yang mengakibatkan luka/sakit sehingga tidak dapat masuk kerja pihak bengkel hanya menaggung sebagian biaya pengobatan dengan membawanya ke rumah sakit terdekat, dan selebihnya para karyawan menaggung sendiri biaya kecelakaan yang terjadi dan bagi karyawan yang sedang luka/sakit tidak diberikan kompensasi dari pihak Bengkel tersebut. ${ }^{22}$

Kecelakaan kerja yang mengakibatkan luka atau sakit seperti: puntung jari karena terkena gerenda itu bisa mengakibatkan karyawan tersebut menjadi cacat tetap karena sudah kehilangan satu jarinya, karena kecelakaan tersebut pekerja tidak bisa masuk kerja dalam beberapa minggu karna perlunya adanya pengobatan yang maksimal, akan tetapi pihak Bengkel Las tidak menaggung biaya karyawan selama karyawan tersebut tidak masuk kerja dalam beberapa minggu, karyawan tidak bisa mencari nafkah untuk keluarganya

21 'Wawancara Dengan Hamdani Hasan, Pemilik Bengkel Kecamatan Tanah Jambo Aye, Pada Hari Kamis, 21 Juni 2018, Di Aceh Utara'.

22 'Wawancara Dengan Edi Kurniawan, Pemilik Bengkel Las Kecamatan Tanah Jambo Aye, Pada Hari Jumat, 22 Juni 2018, Di Aceh Utara'. 
dan biaya pengobatan yang dideritanya karna ketidak pedulian dari pihak Bengkel Las untuk karyawan tersebut. ${ }^{23}$

Yang mana seharusnya Bengkel Las Kecamatan Tanah Jambo Aye setiap pekerja yang mengalami kecelakaan kerja yang mengakibatkan luka atau sakit harus diberikan perawatan kesehatan, kompensasi dan hak-hak para pekerja sesuai dengan hukum islam yang didalamnya dijelaskan tentang hak-hak bagi pekerja yang salah satunya adalah hak untuk hidup, setiap manusia memiliki kewajiban untuk menjaga kehidupan orang lain sebagaimana kehidupan pribadinya dan harus memberikan rasa aman bagi kehidupan oarng lain, agar nyawa mereka tidak terancam. ${ }^{24}$

\section{Risiko Pemeliharaan Kesehatan}

Risiko Kesehatan terjadi ketika seseorang mengalami gangguan kesehatan, yang mana ketika para karyawan tidak memakai alat-alat perlindungan tenaga kerja yang akan mengakibatkan gangguan kesehatan bagi mereka, seperti tidak memakai masker di saat bekerja yang dapat menyebabkan masuknya debu atau partikel yang lebih besar kedalam saluran pernafasan, selalu jongkong dalam bekerja, itu akan mengakibatkan para pekerja sakit pinggang. Kemudian tidak memakai topi pelindung yang dapat menyebabkan kepala karyawan terpukul benda keras atau tajam dan terbentur kepalanya, selanjutnya tidak memakai sarung tangan guna untuk melindungi tangan dan jari dari pejanan api, sengatan listrik, pukulan, tergores, dan terinfeksi dan lain sebagainya. ${ }^{25}$

Sesuai dengan hasil wawancara yang peneliti lakukan dengan Basri selaku karyawan Bengkel Las munuturka, kecelakaan yang terjadi seperti jatuhnya genteng diatas kepala yang bisa mengakibatkan luka parah disebabkan karena disaat karyawan bekerja tidak memakai topi pelindung. ${ }^{26}$

Bengkel Las kecamatan Tanah Jambo Aye seharusnya menyedikan Alat Pelindung Diri(APD) untuk mencegah kecelaan yang terjadi kepada karyawan, sesuai dengan Undang-undang No. 13 Tahun 2003 tentang Ketenagakerjaan bahwasanya setiap pekerja dan keluarganya berhak memperoleh jaminan sosial tenaga kerja. Sebagaiman yang dimaksud dalam pasal 99-101 Undang-undang No. 13 Tahun 2003 Tentang Ketenagakerjaan pengusaha wajib untuk menyediakan fasilitas kesejahteran bagi para pekerjanya.

\section{Bentuk Jaminan Keselamatan Kerja Terhadap Karyawan Bengkel Las Kecamatan Tanah Jambo Aye}

Jaminan Keselamatan kerja merupakan faktor penting dalam pekerjaan, terutama untuk pekerjaan yang berpotensial (kecelakaan) tinggi. Upaya Keselamatan dan kesehatan kerja dimaksudkan untuk memberikan jaminan keselamatan dan meningkatkan derajat kesehatan para pekerja dengan cara pencegahan kecelakaan dan penyakit akibat kerja, pengendalian bahaya di tempat kerja, promosi kesehatan, pengobatan dan rehabilitasi. ${ }^{27}$

Berbicara Mengenai Jaminan Keselamatan kerja, maka yang di maksudkan disini adalah yang bertalian dengan kecelakaan kerja, yaitu kecelakaan yang terjadi di tempat kerja atau dikenal dengan istilah kecelakaan industri. ${ }^{28}$ Ada 4 faktor penyebab dari kecelakaan

23 'Wawancara Dengan Hamdani Hasan, Pemilik Bengkel Kecamatan Tanah Jambo Aye, Pada Hari Jumat, 22 Juni 2018, Di Aceh Utara'.

24 Ahmad Ibrahim Abu Sinn, Manajemen Syariah: Sebuah Kajian Historis Dan Kontemporer (PT Raja Grafindo Persada 2008), hlm. 64-71.

25 'Wawancara Dengan Andi, Karyawan Bengkel Las Kecamatan Tanah Jambo Aye, Pada Hari Jumat, 22 Juni 2018, Di Aceh Utara.'

26 'Wawancara Dengan Basri, Karyawan Bengkel Las Kecamatan Tanah Jambo Aye, Pada Hari Rabu, 20 Juni 2018, Di Aceh Utara'.

27 Hardijan Rusli, Hukum Ketenagakerjaan Bedasarkan UU No.13 Tahun 2003 Tentang Ketenagakerjaan Dan Peraturan Terkait Lainnya (Ghalia Indonesia 2011), hlm. 6.

28 Irzal, Buku Dasar - Dasar Kesehatan \& Keselamatan Kerja (2016); Didin Komarudin, Wowo S Kuswana 
kerja ini, yaitu:

\section{Faktor manusianya}

Misalnya, karena kurangnya keterampilan atau kurangnya pengetahuan, salah penempatannya misalnya pekerja lulusan Sekolah Tinggi Menegah (STM) akan tetapi di tempatkan di bagian tata usaha.

\section{Faktor materialnya/bahannya/peralatannya}

Misalnya, bahan yang di seharusnya di buat terbuat dari besi, akan tetapi supaya lebih murah dibuat dari bahan lainnya sehingga dengan mudah dapat menimbulkan kecelakaan. ${ }^{29}$

\section{Faktor bahaya}

Misalnya, kondisi/ keadaan berbahaya yaitu keadaan yang tidak aman dari mesin/ peralatan, lingkungan, proses, sifat pekerjaan.

\section{Faktor yang di hadapi}

Misalnya, kurangnya pemeliharaan atau perawatan mesin-mesin sehingga tidak bisa bekerja dengan sempurna.

Setiap perusahaan atau bengkel haruslah menerapkan jaminan keselamatan kerja karyawan, namun kenyataannya, masih banyak bengkel-bengkel di Kecamatan Tanah Jambo Aye yang masih menyepelekan hal tersebut. Padahal, Jaminan keselamatan kerja merupakan salah satu hak asasi pekerja dan salah salah satu upaya untuk meningkatkan kualitas kinerja karyawan di bengkel las itu sendiri. Hal ini ditunjukkan dengan masih tingginya tingkat kecelakaan kerja yang terjadi di bengkel-bengkel Kecamatan Tanah Jambo Aye.

Penerapan Jaminan Keselamatan Kerja di bengkel las Kecamatan Tanah Jambo Aye memang belum terlaksana dengan baik secara menyeluruh. Meskipun program keselamatan dan kesehatan kerja (K3) tersebut telah memiliki dasar hukum yang kuat dalam undangundang. Karena Kecelakaan kerja merupakan kejadian yang tak terduga sebelumnya dan tidak diketahui kapan terjadi.

Sebenarnya Bengkel Las Kecamatan Tanah Jambo Aye bisa mencegah kecelakaan tersebut jika saja bengkel las memberikan pelayanan Keselamatan dan kesehatan kerja yang baik terhadap karyawannya serta memberikan jaminan atas kecelakaan tersebut. Sehingga para karyawan merasa aman dan terlindungi dengan adanya program Keselamatan dan kesehatan kerja yang terlaksana di bengkel las tersebut.

Sesuai dengan hasil wawancara yang peneliti lakukan dengan Bapak Idris Ismail selaku pemilik Bengkel Las, Menuturkan bahwa bentuk jaminan dari kami pihak Bengkel yaitu misalnya ada yang sakit atau mengalami kecelakaan akibat kerja kami membawanya ke dokter atau ke rumah sakit Jaminan Keselamatan kerja karyawan dalam bengkel ini ditanggung sesuai dengan kecelakaan yang terjadi pada karyawan, jika kecelakaan yang terjadi itu tidak terlalu bayaha, maka ditanganinnya dengan membawa karyawan ke rumah sakit terdekat, jika kecelakaan yang terjadi itu parah seperti patah kaki karena

and Ridwan AM Noor, 'Kesehatan Dan Keselamatan Kerja Di SMK' [2016] Journal of Mechanical Engineering Education; Bryan J Alfons Willyam Sepang Tjakra, JE Ch Langi and DR O Walangitan, 'Manajemen Risiko Keselamatan Dan Kesehatan Kerja (K3) Pada Proyek Pembangunan Ruko Orlens Fashion Manado' [2013] Jurnal Sipil Statik; Dameyanti Sihombing, DRO Walangitan and Pingkan AK Pratasis, 'Implementasi Keselamatan Dan Kesehatan Kerja (K3) Pada Proyek Di Kota Bitung (Studi Kasus Proyek Pembangunan Pabrik Minyak Pt.Mns)’ [2014] Jurnal Sipil Statik; Edwina Rudyarti, 'Hubungan Pengetahuan Keselamatan Dan Kesehatan Kerja Dan Sikap Penggunaan Alat Pelindung Diri Dengan Kejadian Kecelakaan Kerja Pada Pengrajin Pisau Batik Di Pt. X’ [2017] Jurnal Kesehatan Masyarakat. 
jatuh dari atas ketika lagi memasang teratak, maka pihak bengkel hanya menanggung sebagian saja biaya pengobatannya dan selebihnya karyawan tersebut menaggung sendiri, karena setiap kecelakaan yang terjadi di bengkel ini kami upayakan untuk membantu para karyawan, untuk alat-alat keselamatan kerjanya kami dari pihak bengkel tidak menyediakan dengan lengkap alat-alat tersebut, seperti helm, sarung tangan, sepatu, perlindungan mata, dan masker. Karena banyak karyawan yang tidak mau memakai alatalat pelindung itu, jadi kami dari pihak bengkel tidak menyedikan dengan lengkap alatalat pelindung bagi karyawan.

Jaminan terhadap Keselamatan kerja di Bengkel Las Kecamatan tanah Jambo Aye belum terdaftar di BPJS Ketenagakerjaan, ${ }^{30}$ yang seharusnya setiap kecelakaan yang terjadi di bengkel las bisa di tanggung oleh BPJS Ketenagakerjaan, akan tetapi karena pihak bengkel las Kecamatan Tanah Jambo Aye belum mendaftar di BPJS tersebut, maka para pekerja tidak bisa di tanggung oleh BPJS ketenagakerjaan.

Dari pemaparan diatas dapat diketahui bahwa Bengkel Las Kecamatan Tanah jambo Aye kurang dalam menyelenggarakan upaya jaminan keselamatan kerja, seperti tidak memberika suatu kondisi keselamatan kerja yang optimal seperti tidak menyediakan alat pelindung diri untuk para pekerjanya, yang mana seharusnya pihak Bengkel Las tersebut harus menyedikan secara lengkap Alat Pelindung Diri (APD) untuk para karyawannya guna untuk mencegah kecelakaan yang terjadi di Bengkel Las.

Alat Pelindung Diri (APD) adalah kelengkapan yang wajib yang digunakan saat bekerja sesuai dengan bahaya dan risiko untuk menjaga keselamatan tenaga kerja itu sendiri ataupun orang lain di tempat kerja.

Pada pekerja bengkel las penggunaan alat pelindung diri sangat perlu untuk di perhatikan, Sesuai dengan hasil wawancara yang peneliti lakukan dengan Musliadi selaku Karyawan Bengkel Las menuturkan bahwa karyawan atau pekerja hanya sesekali menggunakan alat pelindung diri seperti masker, kaca mata, sepatu tidak pernah digunakan oleh pekerja disebabkan karena repot untuk menggunakannya dan menyulitkan saat bekerja walaupun pekerjaan yang dilakukan sangat berisiko untuk menciderai tubuh mereka khususnya tangan, dan alat pelindung diri yang lainnya tidak pernah digunakan karena pekerja tidak memiliki alat untuk digunakan, disebabkan pihak perusahaan tidak lengkap dalam menyediakan alat pelindung untuk para pekerjanya. ${ }^{31}$

Penggunaan alat pelindung diri harus diterapkan oleh pekerja karena dengan adanya alat pelindung diri dapat meminimalkan risiko yang akan terjadi pada pekerja.

Setelah membaca pemahaman diatas ternyata Bengkel-bengkel las Di Kecamatan Tahan Jambo Aye tidak memberikan Jaminan Keselamatan Kerja Kepada para karyawannya, yaitu dengan kurangnya mempersiapkan alat-alat pelindung diri kepada para karyawan dan jika terjadi kecelakaan kepada karyawa pihak Bengkel hanya menanggung setengah biaya kecelakaan tersebut.

\section{Tinjauan Perspektif Hukum Islam dan Undang-Undang Keselamatan Kerja Terhadap Karyawan Bengkel Las Kecamatan Tanah Jambo Aye}

Islam merupakan sebuah agama dan sebuah jalan yang mengatur segala bentuk kehidupan dari hal yang terkecil yang di anggap sepele oleh manusia, sampai dengan hal yang terbesar sekalipun, baik itu persoalan hubungan manusia dengan penciptanya

30 'Wawancara Dengan Idris Ismail, Pemilik Bengkel Kecamatan Tanah Jambo Aye, Pada Hari Jumat, 22 Juni 2018, Di Aceh Utara.'

31 'Wawancara Dengan Musliadi, Karyawan Bengkel Las Kecamatan Tanah Jambo Aye, Pada Hari Jumat, 22 Juni 2018, Di Aceh Utara.' 
(ibadah) maupun hubungan manusia dengan sesamanya dan hubungan manusia dengan alam semesta. Tidak ada yang luput dari pantauan Islam. Begitu juga dalam hal bekerja dan memperkerjakan, semuanya diatur dan ditata sedemikian rupa, sehingga mampu menerbitkan kehidupan manusia.

Begitulah kehidupan manusia, yang tidak bisa hidup sendiri dan saling membutuhkan sesamanya. Bengkel Las Kecamatan Tanah Jambo Aye membutuhkan tenaga karyawan untuk membantunya menjalankan tugas-tugas yang sangat banyak, sedangkan karyawan membutuhkan uang yang bisa ditukar dengan tenaga yang dia miliki.

Agama Islam sangat menganjurkan Keselamatan umat manusia di dunia maupun di akhirat. Dalam kehidupaan sehari-hari, manusia tidak lepas dari ancaman-ancaman yang akan akan membahayakan diri dan keluarga. Sebagaimana firman Allah dalam surat AtTaghabun: 11:

Artinya:" Tidak ada sesuatu musibah pun yang menimpa seseorang kecuali dengan izin Allah; dan barang siapa yang beriman kepada Allah, niscaya Dia akan memberi petunjuk kepada hatinya, Dan Allah maha mengetahui segala sesuatu (Qs.AtTaqhabun/64:11).

Keselamatan terhadap pekerja Merupakan suatu keharusan yang harus dilakukan oleh pemberi kerja dalam hal ini baik pemerintah maupun swasta. Perlindungan yang harus di perhatikan sekurang-kurangnya adalah kebutuhan dasar pekerja. Imam Asy-Syatiby menggolongkan kebutuhan manusia kedalam tiga golongan yang di kenal dengan konsep Maqashid Syari'ah, yaitu: ${ }^{32}$

Dharuriyat: Meliputi jiwa, agama, akal, keturunan dan harta. Yang mana ini adalah kebutuhan primer yang jika tidak dipenuhi maka keselamatan manusia dunia dan akhirat akan terancam.

Hajjiyat: yaitu kebutuhan sekunder, Jika kebutuhan ini tidak terpenuhi maka tidak akan terancam keselamatan manusia, tapi akan mendatangkan kesulitan.

Tahsiniyyat: Kebutuhan ini adalah kebutuhan pelengkap, jika tidak terpenuhi maka tidak mengancam keselamatan dan tidak menimbulkan kesulitan.

Keselamatan terhadap Pekerja dapat digolongkan kepada kebutuhan Dharury dimana keselamatan ini meliputi jiwa,agama,akal, keturunan.

Menurut Observasi yang sudah peneliti lakukan Keselamatan kerja atau risiko-risiko yang terjadi terhadap para Karyawan di Bengkel Las Kecamatan Tanah Jambo Aye belum tercapai sebagaimana Konsep Keselamatan Kerja dalam Islam dan belum berjalan dengan maksimal di karnakan kurangnya kepedulian dari pihak Bengkel Las yang masih kurang dalam menyediakan alat-alat perlindungan kerja terhadap para karyawannya dan belum sepenuhnya para pekerja ditanggung risiko Kecelakaan yang terjadi dan para karyawannya belum didaftarkan dalam BPJS Ketenagakerjaan.

Keselamatan terhadap risiko yang terdapat pada Bengkel Las Kecamatan Tanah Jambo Aye belum memenuhi kriteria kebutuhan dharury diantaranya perlindungan yang paling utama yaitu perlindungan jiwa, hal ini bisa dilihat dari upaya keselamatan kerja terhadap para karyawan di Bengkel Las Kecamatan Tanah Jambo Aye, baik dari peralatan kerja yang belum lengkap dan kurang dalam mengoptimalkan keselamatan kerya karyawan.

Keselamatan dan kesehatan Kerja merupakan hak dari seorang pekerja, dan suatu kewajiban bagi pengusaha. Hal ini diatur dalam Undang-undang No.13 Tahun 2003

32 Satria Effendi, Ushul Fiqh (Kencana 2009), hlm. 234. 
tentang Ketenagakerjaan pasal 86 ayat (1),Yaitu:

Setiap pekerja/buruh mempunyai hak untuk memperoleh perlindungan, atas:

- Keselamatan dan kesehatan kerja,

- Moral dan kesusilaan, dan

- Perlakuan yang sesuai dengan harkat dan martabat manusia serta nilai-nilai agama.

Untuk melindungi keselamatan pekerja/buruh guna mewujudkan produktivitas kerja yang optimal diselenggarakan upaya keselamatan dan kesehatan kerja Perlindungan sebagaimana yang di maksud dalam ayat (1) dan ayat(2). ${ }^{33}$

Dalam Undang-undang No. 13 Tahun 2003 Tentang Ketenagakerjaan telah mengatur dengan jelas tentang Keselamatan dan perlindungan terhadap pekerja atau karyawan dan kewajiban bagi pengusaha untuk melindungi keselamatan para pekerjanya. Penerapan Jaminan Keselamatn kerja pada Bengkel Las Kecamatan Tanah Jmbo Aye tidak memiliki relevansi yang kuat dengan Undang-undang No.13 Tahun 2003 Tentang Ketenagakerjaan. Seperti tidak terpenuhinya jaminan terhadap keselamatan pekerja dan risiko yang dialami, yang mana pihak Bengkel Las Belum membuat peraturan dan menempel posterposter di Bengkel Las tentang kewajiban memakai alat kerja pengaman dan sanksinya dan tentang membudayakan keselamatan dan kesehatan kerja di lingkungan Bengkel Las Kecamatan Tanah Jambo Aye. Oleh karena itu untuk selanjutnya dibutuhkan upaya yang lebih baik dari Pihak Bengkel Las Kecamatan Tanah Jambo Aye agar mendapatkan suatu nilai kesejahteraan bagi kedua belah pihak yaitu pekerja dan pengusaha itu sendiri.

\section{KESIMPULAN}

Berdasarkan Pembahasan yang telah dipaparkan dalam bab-bab sebelumnya, maka dalam bab penutup ini penulis akan merangkum beberapa kesimpulan yang perinciannya sebagai berikut:

sistem jaminan keselamatan kerja karyawan Bengkel Las Kecamatan Tanah Jambo Aye tidak sepenuhnya ditanggung oleh bengkel Las tersebut, yang mana jika terjadi kecelakaan terhadap karyawan yang disebabkan oleh bengkeL Las tersebut, maka pihak bengkel hanya menanggung setengah dari biaya pengobatan yang dialami oleh karyawan tersebut. Dan Bengkel las Tersebut tidak memberikan suatu kondisi keselamatan kerja yang optimal, seperti tidak menyediakan Alat Pelindung Diri (APD) secara efektif dan maksimal kepada karyawan yaitu berupa: sarung tangan, topi pelindung, alat pelindung mata, alat pelindung wajah, alat pelindung pernafasan, dan alat pelindung kaki. Disebabkan karena Bengkel Las tersebut kurang dari segi dananya untuk menyediakan Alat Pelindung Diri secara lengkap yang mana pemesan-pemesan pagar,pintu, canopy, tratak, dan lain sebagainya tidak membayar secara cash atau lunas uangnya, akan tetapi mereka membayar secara menyicil.

sistem jaminan keselamatan kerja karyawan Bengkel Las Kecamatan Tanah Jambo Aye kurang sesuai dengan hukum Islam dan Undang-undang No.13 Tahun 2003 Tentang ketenagakerjaan. Karena dalam hukum Islam telah di jelaskan tentang konsep Maqashid Syari'ah yang terdiri dari lima Maqashid Syari'ah salah satu diantaranya yaitu melindungi jiwa. dan pada Bengkel Las tersebut Kurang menjamin keselamatan terhadap karyawan sehingga hal tersebut kurang sesuai denganmaqashid Syar'iah dalam menjaga keselamatan jiwa para karyawannya. dan terkait dengan Undang-undang No. 13 tahun 2003 Tentang

33 'Kompilasi Hukum Ketenagakerjaan Dan Jamsostek' (Pustaka Yustisia), hlm. 31-33. 
Ketenagakerjaan disebutka dalam pasal 86 yaitu Setiap pekerja/buruh mempunyai hak untuk memperoleh perlindungan, sedangkan pada Bengkel Las tersebut Kurang memperhatikan Perlindungan dan jaminan terhadap karyawan.

\section{SARAN}

Kepada Bengkel las Kecamatan Tanah Jambo Aye agar terus memberikan penyuluhan tentang kesehatan yang berkaitan dengan pemakaian Alat Perlindungan Diri saat bekerja serta Keselamatan dan kesehatan kerja juga diharapkan agar selalu mengawasi pekerja dalam pemakaian alat pelindung diri. Dan bagi pekerja agar mematuhi dan menyadari akan pentingnya menggunakan alat pelindung diri saat bekerja agar terhindar dari kecelakaankecelakaan kerja. dan masih perlu adanya koordinasi yang aktif antara pihak perusahaan dengan karyawannya, sehingga terjalin hubungan kerja yang aman kedepannya.

Banyaknya pekerja yang belum terdaftar dalam BPJS Kesehatan, Kepada Bengkel Las Kecamatan Tanah Jambo Aye agar terus memperhatikan dan memberikan pengetahuan kepada pekerja akan pentingnya hal tersebut sehingga dapat terjamin kesejahteraan pekerja.

\section{DAFTAR PUSTAKA}

Agusmidah, Hukum Ketenagakerjaan Indonesia (Ghalia Indonesia 2010)

Ahmad Ibrahim Abu Sinn, Manajemen Syariah: Sebuah Kajian Historis Dan Kontemporer (PT Raja Grafindo Persada 2008)

Alfons Willyam Sepang Tjakra BJ, Ch Langi JE and O Walangitan DR, 'Manajemen Risiko Keselamatan Dan Kesehatan Kerja (K3) Pada Proyek Pembangunan Ruko Orlens Fashion Manado' [2013] Jurnal Sipil Statik

Anwar K, Asuransi Syariah, Halal Dan Maslahah (Tiga Serangkai)

Asikin Z, Dasar-Dasar Hukum Perburuhan (PT Raja Grafindo Persada 2006)

Barthos B, Manajemen Sumber Daya Manusia, Suatu Pendekatan Makro (Bumi Aksara 2001)

_—, Manajemen Sumber Daya Manusia Suatu Pendekatan Makro (Bumi Aksara 2012)

Departemen Pendidikan Nasional, Kamus Besar Bahasa Indonesia Pusat Bahasa (Gramedia 2008)

H.Manulag S, Pokok-Pokok Hukum Ketenagakerjaan Di Indonesia (Rineka Cipta 2001)

Hardijan Rusli, Hukum Ketenagakerjaan Bedasarkan UU No.13 Tahun 2003 Tentang Ketenagakerjaan Dan Peraturan Terkait Lainnya (Ghalia Indonesia 2011)

Irzal, Buku Dasar - Dasar Kesehatan \& Keselamatan Kerja (2016)

Kasmir, Kewirausahaan (PT Raja Grafindo Persada 2006)

Komarudin D, Kuswana WS and Noor RA, 'Kesehatan Dan Keselamatan Kerja Di SMK' [2016] Journal of Mechanical Engineering Education

'Kompilasi Hukum Ketenagakerjaan Dan Jamsostek' (Pustaka Yustisia)

M.Nazir, Metode Penelitian (Ghalia Indonesia 1998)

Oktav P . Zamani, Pedoman Hubungan Industrial (PPM 2011)

Qorashi BS, Keringat Buruh, Hak Dan Peran Pekerja Dalam Islam (Al-huda 2007) 
Rivai V, Manajemen Sumber Daya Manusia Untuk Perusahaan, Dari Teori Ke Praktik (PT Raja Grafindo Persada 2009)

Rosyid A, Manajemen Sumber Daya Alam Manusia (Erlangga 1999)

Rudyarti E, 'Hubungan Pengetahuan Keselamatan Dan Kesehatan Kerja Dan Sikap Penggunaan Alat Pelindung Diri Dengan Kejadian Kecelakaan Kerja Pada Pengrajin Pisau Batik Di Pt. X' [2017] Jurnal Kesehatan Masyarakat

Satria Effendi, Ushul Fiqh (Kencana 2009)

Sihombing D, Walangitan DRO and Pratasis PAK, 'Implementasi Keselamatan Dan Kesehatan Kerja (K3) Pada Proyek Di Kota Bitung (Studi Kasus Proyek Pembangunan Pabrik Minyak Pt.Mns)' [2014] Jurnal Sipil Statik

Sula MS, Asuransi Syariah (Life and General): Konsep Dan Sistem Operasional (Gema Insani Press 2004)

Suratmaputra AM, Filsafat Hukum Islam Al-Ghazali (Pustaka Firdaus 2002)

'Wawancara Dengan Andi, Karyawan Bengkel Las Kecamatan Tanah Jambo Aye, Pada Hari Jumat, 22 Juni 2018, Di Aceh Utara.'

'Wawancara Dengan Basri, Karyawan Bengkel Las Kecamatan Tanah Jambo Aye, Pada Hari Rabu, 20 Juni 2018, Di Aceh Utara'

'Wawancara Dengan Edi Kurniawan, Pemilik Bengkel Las Kecamatan Tanah Jambo Aye, Pada Hari Jumat, 22 Juni 2018, Di Aceh Utara'

'Wawancara Dengan Hamdani Hasan, Pemilik Bengkel Kecamatan Tanah Jambo Aye, Pada Hari Kamis, 21 Juni 2018, Di Aceh Utara'

'Wawancara Dengan Idris Ismail, Pemilik Bengkel Kecamatan Tanah Jambo Aye, Pada Hari Jumat, 22 Juni 2018, Di Aceh Utara.'

'Wawancara Dengan Muliadi, Karyawan Bengkel Las Kecamatan Tanah Jambo Aye, Tanggal 23 September 2017'

'Wawancara Dengan Musliadi, Karyawan Bengkel Las Kecamatan Tanah Jambo Aye, Pada Hari Jumat, 22 Juni 2018, Di Aceh Utara.'

'Wawancara Dengan Nasruddin, Camat Kecamatan Tanah Jambo Aye, Pada Hari Senin, 25 Juni 2018, Di Aceh Utara.'

'Wawancara Dengan Razali, Pemilik Bengkel Kecamatan Tanah Jambo Aye, Pada Hari Rabu, 20 Juni 2018, Di Aceh Utara.'

'Wawancara Dengan Razali, Pengusaha Bengkel Las Kecamatan Tanah Jambo Aye, Tanggal 2 September 2017.' 